\title{
A suicide survivor: the life of a Chinese worker
}

\author{
Jenny Chan
}

\begin{abstract}
In 2010, 18 employees working for Foxconn in China attempted suicide. These shocking events focused the world's attention on the manufacturing supply chains of China's export industry and the experience of working within them. What had driven these young, migrant, assembly line workers to commit such a desperate act? This article provides a first-hand account of the experiences of one of those who survived a suicide attempt, 17-year-old Tian Yu. Her personal narrative is embedded within the broader context of labour process, work organisation and managerial practice at Foxconn, the Taiwaneseowned multinational that provides products and components for Apple and others. The factory conditions are further shaped by the company trade union and Chinese government policies. The paper concludes with additional contextualisation indicating the emergence of an alliance of workers, students, scholars and transnational labour movement activists who are campaigning for Chinese workers' rights.
\end{abstract}

Keywords: Foxconn, suicides, Apple, global supply chains, wages, working hours, Chinese workers, ACFTU (All-China Federation of Trade Unions).

\section{Introduction}

Among the most prominent firms in the global supply chain that operates in China is Foxconn, the Taiwanese-owned multinational electronics contract supplier. Foxconn is the trading name for Hon Hai Precision Industry Company and, with a workforce of 1.4 million, is the largest private sector company in China and is one of the world's largest employers (iSuppli, 30 May 2006; 27 July 2010; BBC, 20 March 2012). Through its manufacture of products for firms, markets and consumers in the United States, Europe and elsewhere, it epitomises the development of China's export-oriented industry. Foxconn's remarkable expansion throughout China gave rise to a mythology of corporate success until a much-publicised spate of employee suicides at its factories and dormitories in 2010 that focused the world's attention on the dark side of its employment regime. One of those who attempted suicide was 17-year-old Tian Yu.

$\square$ Jenny Chan (wlchan_cuhk@yahoo.com) is a Ph.D. candidate, Great Britain-China Educational Trust Awardee and Reid Research Scholar in the Faculty of History and Social Sciences at the University of London, Royal Holloway. She serves as an advisor to Hong Kong-based labour rights group SACOM (Students and Scholars Against Corporate Misbehavior). In collaboration with Ngai Pun and Mark Selden, she is writing a book entitled Separate Dreams: Apple, Foxconn and a New Generation of Chinese Workers. 
At about 8 a.m. on March 17, 2010, after only 37 days of employment, Yu threw herself from the fourth floor of Foxconn's Longhua dormitory in Shenzhen (South China Morning Post, 19 July 2012; 25 April 2013). Miraculously she survived, but suffered three spinal fractures, four hip fractures, and was left paralysed from the waist down. Her job at the Longhua factory had been her first, and probably will be her last. This paper is structured around her account of the circumstances behind, and consequences of, the desperate attempt to take her own life.

Her personal narrative, examined within the broader context of the spate of suicides at Foxconn, provides an insight into the human consequences of the labour regimes of the globalised manufacturing supply chains of China's export industries (Lee, 1998; Pun, 2005; Lichtenstein, 2009; Bonacich and Hamilton, 2011; Chan, 2011a). The counterpoint to the contemporary fascination with i-products is a regime of managerial autocracy and assembly line drudgery at the point of production, a contradiction that reminds us of the enduring relevance of Marx's concept of commodity fetishism. Thousands of miles from the shelves of the Apple store, and ordinarily concealed from consumer concern, lies the reality of alienating toil that, in extreme conditions, contributes to individual tragedies such as Yu's.

During 2010, 18 young workers, ranging in age from 17 to 25, attempted suicide at Foxconn facilities in China. Fourteen died, whereas four survived with crippling injuries (Chan, 2011b). International media dubbed these events the 'suicide express' (Daily Mail, 29 May 2010). Facing public criticism, Foxconn strove to minimise reputational damage by claiming that the suicide rate at its plants was below the national rate of 23 per 100,000 people (Phillips et al., 2002). Liu Kun, the corporate public communications director, emphasised that Foxconn had more than 1,000,000 employees in China alone, and that the reasons for suicides were multiple. 'Given its size, the rate of self-killing at Foxconn is not necessarily far from China's relatively high average', reported The Guardian (28 May 2010). But no scientific study would draw a comparison which ignores the fact that the suicides were by young people employed by a single company, the great majority working in a small industrial district of Shenzhen. Scientific comparisons would require that data be randomly drawn from a district with similar population size and age groups. It would make little sense, for example, to compare the workers' suicides to patterns among the disadvantaged rural women and the elderly who made up a large proportion of the country's suicide cases (Ji et al., 2001, Lee and Kleinman, 2003; China Economic Review, 28 May 2010). The Foxconn suicide cluster represents a phenomenon that has no precedent in China's industrial history.

It is hoped that the following testimony of Yu will contribute to an understanding of this wave of suicides and, more broadly, will assist in the necessary scrutiny of the Chinese and global contexts of international capital, which link Foxconn, electronic consumer product brands, and the Chinese government (Chan, 2010; 2012; Chan and Pun, 2010; Pun and Chan, 2012). This paper interweaves Yu's testimony with Foxconn's shop floor practices and will conclude with a discussion of the roles of the local government and the All-China Federation of Trade Unions (ACFTU), the organisation that ostensibly represents workers, and their responses to the suicides.

\section{Fieldwork in China}

Since summer 2010, and in the wake of the suicides and reports of corporate abuses, faculty members and students from 20 universities in mainland China, Taiwan and Hong Kong have formed the University Research Group on Foxconn. Together with Students and Scholars Against Corporate Misbehavior (SACOM), ${ }^{1}$ a Hong Kong-based transnational campaign group, international researchers have conducted independent investigations into Foxconn's labour practices and production systems (see January 2013 special issue of the South Atlantic Quarterly, Litzinger, 2013; Pun and Chan, 2013; Pringle, 2013; Hung, 2013). The author is one of the principal Hong Kong Chinese field researchers who have interviewed Foxconn workers, managers, government officials and labour rights activists in Hong Kong, Shenzhen (Longhua and Guanlan towns in 
Guangdong province), Chengdu (provincial city of Sichuan) and Chongqing municipality, and a labour rights advocate affiliated to SACOM.

In addition to extended interviews with $\mathrm{Yu}, 42$ additional interviews have been conducted by the author with current or former workers offsite, where they were not subject to managerial surveillance and thus retaliation. When undertaking such fieldwork the research team members identified themselves as a group in order to protect the anonymity of individual university researchers (particularly those full-time undergraduate and postgraduate students based in mainland China) and frontline labour activists from company harassment or local government censorship. Such anonymity was essential given the close alliance between Foxconn managers and government officials across all four municipalities (Beijing, Shanghai, Tianjin and Chongqing) and 15 provinces, in which Foxconn has huge investments in production and research and development facilities (Chan et al., 2013).

\section{Tian Yu's story}

The first meeting with Yu was in July 2010 at the Shenzhen Longhua People's Hospital in Guangdong province, where she was recovering from the injuries sustained in her suicide attempt. Aware of Yu's fragile physical and psychological state, the researchers were fearful that their presence might cause Yu and her family further pain. However, both Yu's mother, at her bedside, and Yu herself when she awoke, welcomed their presence.

The researchers sought to understand the nature of the 'private troubles' that had driven her attempted suicide and to channel this insight as a contribution to making these conditions a 'public issue' (Mills, [1959] 2000; Webster et al., 2008). Over the following weeks, as Yu regained her faculties and established bonds of trust with the researchers, she recalled her family background and the circumstances that had led to her being employed at Foxconn, her experiences working on the assembly line and living in the company dormitory. During interviews it became clear that Yu's problems were not individual or 'psychological' but were faced by many Foxconn employees.

\section{From farm to factory}

The personal journey undertaken by $\mathrm{Yu}$, migrating from the countryside to employment as a young worker in the expanding workforce of China's export-oriented manufacturing industry is not atypical: 'I was born into a farming family in February 1993 in a village near Laohekou City, Hubei Province, central China. My grandmother brought me up while my parents were earning money as factory workers far away from home'.

Yu belonged to the generation of 'left-behind children', as the first rural-to-urban migration wave enveloped China's countryside. Since the mid-1980s, the deterioration of the rural economy under the urban-based state development policy, and the increased market pressures following China's accession to the World Trade Organization in 2001, brought about unprecedented challenges to China's vast peasantry.

At best my family could earn about 15,000 yuan on the land in a year [approximately US\$2,380], hardly enough to sustain six people... Some years later my parents returned home with just enough money to renovate the house.

Rural reconstruction as a multidimensional project that integrates social and economic goals has been flawed and remains undeveloped (Selden, 1993; Day and Hale, 2007). Despite the elimination of agricultural taxes in the mid-2000s, the countryside has remained stagnant as youth have left en masse for the cities. Personal decisions to leave home are shaped by both sociocultural and economic concerns. Young rural residents increasingly express a desire to broaden their horizons and experience a modern life and cosmopolitan consumption in megacities such as Shenzhen, on the northern border of Hong Kong (Harney, 2008). 
Internet technology and mobile communications has opened a window on the wealthy, wonderful city lifestyle for us. Almost all the young people of my age, including my school friends, had gone off to work, and I was excited to see the world outside too. Upon completing a course at the local vocational school, I decided to leave the province to seek new opportunities, with my parents' support.

Soon after the Spring Festival in early February 2010, Yu's father gave her about 500 yuan (approximately US\$80) to support her search for work in the coastal Guangdong province, and provided her with a second-hand cell phone so that she could call home. He asked her to be safe.

My cousin brought me to the long-distance coach station. I was joining many rural youth leaving the land to find jobs in the city. It was the first time in my life that I was far away from home, my familiar place, food and people ... Getting off the coach, my first impression of the industrial town was that Shenzhen was nothing like what I had seen on TV.

\section{Arriving at Shenzhen-entering Foxconn}

In 1980, Shenzhen was the first special economic zone opened to overseas Chinese and foreign investments. Since 1988, Foxconn has built many factories in southern China, the heart of the nation's export-oriented development and an area where labour and environmental regulations were weak and enforcement even weaker (Andors, 1988; Chan, 2001). Foxconn has expanded and diversified, taking advantage of favourable tax policies and low-cost land and water for these electronics start-ups. The result has been the creation of huge new workforces and a dependence on the continuous supply of labour from the countryside. New employees have experienced a depersonalised induction process, as depicted by Yu.

At the Foxconn Recruitment Center, I queued up for the whole morning, filled out the job application form, pressed my fingertips onto the electronic reader, scanned my identity card, and took the blood test to complete the health check procedures. On 8 February 2010, I was employed as a general assembly-line worker. Foxconn assigned me staff number F9347140. That same afternoon I received a brief company introduction about the working hours and rules and regulations at Foxconn's Guanlan factory. I also obtained a pocket-sized, color-printed Foxconn Employee Handbook.

The preface of this Handbook is replete with morale-boosting language: 'Hurry toward your finest dreams, pursue a magnificent life. At Foxconn, you can expand your knowledge and accumulate experience. Your dreams extend from here until tomorrow'. The instructor at employee orientation told stories of entrepreneurs like CEOs Steve Jobs and Bill Gates to inspire new workers. Foxconn propagates this dream of riches through labour, the belief that success is possible through diligent work.

Then, I and the hundreds of other new workers were taken to the Longhua factory, about an hour ride by the company bus. In a late afternoon, the setting sun bathed the Foxconn facilities in golden light. At 5 p.m. thousands and thousands of Foxconn workers poured out of the factory gate.

Longhua is the flagship manufacturing base of Foxconn, where workers are assigned to day and night shifts on assembly lines. It is a key node in the global production network, where the assembly and shipment of finished products to world consumers continues around the clock 365 days a year. Container trucks and forklifts rumble non-stop, serving a grid of factories that churn out iPhones, iPads and other electronic products. Yu became one of the 400,000-strong Foxconn Longhua workforce, most of whom, similarly, were young rural migrants in their late-teens to early twenties.

\section{My introduction to factory work}

There are 12 business groups in the Foxconn company, which compete on 'speed, quality, engineering service, efficiency and added value' to maximise profits (Foxconn Technology Group, 2009: 8). Among them, iDPBG (integrated Digital Product Business Group) and iDSBG (innovation Digital System Business Group) exclusively serve 
Apple in components manufacture and final assembly. The other business groups tailor production for Microsoft, IBM, Samsung, Amazon, HP, Dell, Sony and other premium brands.

My assembly-line position was at the iDPBG. I arrived late for my first day of work. The factory was too big, and I got lost. So I spent a long time looking for the iDPBG workshop. The factory directory shows that there are ten zones listed from $\mathrm{A}$ to $\mathrm{H}, \mathrm{J}$, and $\mathrm{L}$, and they are further subdivided into $\mathrm{A} 1$, A2, A3, L6, L7, J20, and so on. It takes almost an hour to walk from the south main gate to the north main gate, and another hour to walk from the west to the east gate. I did not know what each building was, nor did I know the meaning of the English acronyms that could be seen written everywhere, such as FIH [Foxconn International Holdings] and the JIT [just-in-time] Hub.

Foxconn's working hours are notoriously long, as Yu soon experienced.

Each production line in my workshop had from a few dozen to more than 100 workers. I was responsible for spot inspections of glass screens to see whether they were scratched. I woke up at 6:30 a.m., attended an unpaid morning meeting at 7:20 a.m., started work at 7:40 a.m., went to lunch at 11, and then usually skipped the evening meal to work overtime until 7:40 p.m.

I attended compulsory unpaid work meetings every day. I reported to the line leaders 15 to 20 minutes earlier for roll call. Leaders lecture us on maintaining high productivity, reaching daily output targets and keeping discipline.

There seemed to be no way for me to say 'no' to overtime . . Toilet breaks during the working hours are also restricted. I had to swipe my staff ID card at electronic readers at the beginning and end of my work shift. I had to ask permission from the assistant line leaders to leave my seat.

The assembly lines run on a 24-hour non-stop basis, the well-lit shop floor visible from afar.

I was switched to the night shift in March. Checking the screens of the products made my eyes feel intense pain. Working twelve-hour days with a single day off every second week, there's no spare time to use the facilities like swimming pools, or to window shop for smartphones in the commercial districts within the enormous complex.

\section{A harsh production regime}

Foxconn has adopted a production model apparently based on classic Taylorism. The production process is simplified to an extreme degree so that workers need no specialised knowledge or training to perform most tasks. Technicians from the industrial engineering department regularly use stop watches and computerised engineering devices to test workers. If they are able to meet the quota, targets are increased to the maximum possible. On the iPhone assembly line, another worker described how her tasks were measured to precise seconds: 'I take a motherboard from the line, scan the logo, put it in an anti-static bag, stick on a label and place it on the line. Each of these tasks takes two seconds. Every ten seconds I finish five tasks' (Interview, 15 October 2011).

As production ramps up, workers face serious problems if they are unable to complete orders within specified time frames. In some departments where workers normally take a 10-minute break, those who fail to meet the hourly production target are not allowed to rest. New workers, like $\mathrm{Yu}$, are repeatedly reprimanded for working 'too slowly' on the line, even when they strive to keep up with the 'standard' work pace. She recalled posters on the Foxconn workshop walls and between staircases that read:

Value efficiency every minute, every second.

Achieve goals or the sun will no longer rise.

The devil is in the details.

Foxconn's ' $8 S^{\prime}$ ' policy is built upon the ' $5 S^{\prime}$ Japanese management method to improve efficiency and organisational performance, which refers to Seiri (sort), Seiton (set in order), Seiso (clean), Seiketsu (standardise the first '3S' procedures), Shitsuke (sustain 
the efforts of seiri, seiton, seiso and seiketsu), to which are added Safety, Saving and Security to the Taiwanese/Chinese system. Such principles are enforced rigorously, as Yu experienced.

Frontline workers' sitting or standing posture is monitored as much as the work itself: 'I had to sit in a standardized way. Stools have to be in order, and cannot move past a yellow and black 'zebra line' on the floor'. Foxconn's industrial engineering aims to make all workers' operations, up to the minutest movements, ever more rationalised, planned and measured. Each assembly-line worker specialises in one specific task and performs repetitive motions at high speed, hourly, daily and for months on end. This 'advanced' production system removes feelings of freshness, accomplishment or initiative toward work: 'I found it hard to see the end of the screen-inspection work', Yu reflected.

\section{Discipline and punishment}

A collection of quotations on the work philosophy of Foxconn's CEO, Terry Gou, adorn the factory walls and are regarded as holy writ, expressing the entrepreneurial spirit and relentless work ethos:

Growth, thy name is suffering.

A harsh environment is a good thing.

Execution is the integration of speed, accuracy and precision.

Outside the lab, there is no high-tech, only execution of discipline.

Gou bases his management model on his military experience and insists on absolute obedience from top to bottom in a chain of command: 'An army of a thousand is easy to get, one general is tough to find'. The 13-level Foxconn management hierarchy is organised in a pyramid with clear lines of command. Senior leaders formulate the corporate development strategy and set annual profit goals. Middle management devise implementation plans and delegate responsibility while, in the workshop, production operators face intense supervision from multiple layers of management, including assistant line leaders, line leaders, team leaders and supervisors. Yu confirmed that while preparing to start work on the production line, frontline managers demand workers respond to the question, 'How are you?', by shouting in unison, 'Good! Very good! Very, very good!'

A long work day of enforced silence, apart from the noise of the machines, is the norm. Yu recalled that,

Friendly chit-chat among co-workers is not very common even during the break; everyone rushes to queue up for lunch and eat quickly. The company prohibits conversation in the workshop. In the factory area, CCTV cameras are set up virtually everywhere for surveillance. Thousands of security officers are on duty, patrolling every Foxconn factory building and dormitory. Special Security Zones are commonplace. In order to enter the iDPBG shop floor, I had to pass through layers of electronic gates and inspection systems. The entry access system is very strict. We were not allowed to bring cellphones or any metallic objects into the workshop. If there was a metal button on my clothes, it had to be removed, otherwise I wouldn't be allowed in, or they [security officers] would simply cut the metal button off.

In order to maintain strict confidentiality for buyers like Apple, HP and Microsoft, Foxconn retains a veritable army of private security officers. Foxconn justifies this surveillance system by its contractual responsibility to secure its customers' rights to intellectual property, in which any leak of 'business information' will result in big financial losses. In this way, global technology multinationals transmit extreme pressure to the Chinese shop floor. Equipment like notebook computers, diskettes, flash drives and multimedia recording devices are strictly barred at Foxconn.

Foxconn's management practices and corporate culture are perceived as punishment-oriented, despite the company human resources rhetoric of 'mutual care and love' (Lucas et al., 2013). Chan and Wang (2004) and Hsing (1998) have examined the Taiwanese managerial style on export-oriented Chinese factories. Yu reiterated: 
I didn't make any mistakes on the products, but the line leader blamed me anyway ... I saw a girl who was forced to stand at attention for hours for supposedly making an error. Public humiliations occurred several times during the working month.

Line leaders, themselves under pressure to fulfill their own production norms, treat workers harshly to reach targets. A young line leader reported, 'If we listen too much to our superiors, we have to mistreat workers below us. If we take care of the workers' feelings too much, maybe we won't complete our tasks. When work is busy, it's easy to get angry' (Interview, 17 October 2011).

In a group interview, several young women employees discussed the ritualistic punishment that they had to endure (Interview, 30 March 2011). Their collective experience was articulated most clearly by one of this group.

After work, all of us-more than 100 people-are [sometimes] made to stay behind. This happens whenever a worker is punished. A girl is forced to stand at attention to read aloud a statement of self-criticism. She must be loud enough to be heard. Our line leader would ask if the worker at the far end of the workshop could hear clearly the mistake she has made. Oftentimes girls feel they are losing face. It's very embarrassing. Her tears drop. Her voice becomes very small ... Then the line leader shouts: 'If one worker loses only one minute [failing to keep up with the work pace], then, how much more time will be wasted by 100 people?

\section{'A massive place of strangers'}

Yu worked on the production line for more than a month and never made friends. 'Heart to heart, Foxconn and I grow together' reads a bright red Foxconn banner above the production line. It suggests that the workers and the company identify with each other but, behind the image of 'a warm family with a loving heart', the life of a Foxconn worker is atomised. The profound loneliness and displaced lives of young migrant workers has been reported in other studies (Jacka, 2006; Yan, 2008). Yu's experience illustrates the difficulty of forming meaningful social relationships in a mega-factory where workers are individualised and pitted against each other to achieve incessant and excessive production demands.

Foxconn's practice of rotating day and night shifts not only affects workers' rest but also hinders their ability to set up networks of social support. With roommates often working different shifts, it is difficult to rest or fulfill their need to socialise. When speaking of her dormitory roommates, Yu recalled, 'We were not close. Random dormitory reassignments break up friendships, increasing our isolation. Although eight girls were housed in the same room, we were strangers to each other. Some of us had just moved in as others moved out. None of the roommates was from Hubei'. Yu's father explained the significance of this experience. 'When she first came to Shenzhen, sometimes when others spoke, she couldn't understand much'. While Mandarin is the national language in China, local dialects are commonly used among people from their native place, and these sublanguages often cannot be comprehended by outsiders.

In school, by contrast, my classmates and I often had time for relaxation and fun, we celebrated birthdays and sang songs. At Foxconn, when I felt lonely, I would sometimes chat on QQ online.

But those logging on to the QQ groups in the Internet space ${ }^{2}$ are bound to remain distant. 'In Foxconn's Longhua factory, with none of my good friends or family members around, it's a massive place of strangers'.

\section{The accumulation of despair}

After I had worked a month, when it was time to distribute wages, everyone else got their wage debit cards, but I did not. I asked the line leader what had happened. The line leader said that although I worked at Longhua, my wage card was at another Foxconn factory in Guanlan town.

Yu had been interviewed at the Recruitment Center in Foxconn Guanlan before being sent to the Longhua facility. The Human Resources Department at Guanlan had kept her personal file and the documents had not been transferred, so that her debit bank 
account at Foxconn Longhua had not been set up. Consequently, she did not receive her pay. 'I had no choice but to take a bus to Foxconn Guanlan on my own'. The Guanlan factory, which began production in summer 2007, now employed 130,000 workers. In an unfamiliar factory compound, 'I went to Block C10, B1, B2, and from floor to floor of building after building to inquire about my wage card'.

After a fruitless day of searching for the right office, with managers and administrators deflecting responsibility, she was unable to find information about her wage card. She recalled: 'I went from office to office by myself but no one would point me in the right direction. They all brushed me off, telling me to ask someone else'. She never received pay for a month of work, approximately 1,400 yuan (US\$220) consisting of a basic pay of 900 yuan plus overtime premiums.

By then it was the middle of March 2010, and after more than one month in Shenzhen I had spent all of the money my parents had given me. Where could I borrow money? At this moment of crisis my cellphone broke. I was unable to get in touch with my cousin in Shenzhen, my sole link to home and family. I could find no one to help me.

The accumulated effects of endless assembly line toil, punishing work schedules, harsh factory discipline, a friendless dormitory and, rejection from managers and administrators, compounded by the company's failure to provide her with income, and then her inability to make contact with friends and family, were the immediate circumstances of her attempted suicide. Her testimony reveals how she was overwhelmed, 'I was so desperate that my mind went blank'.

At 8 a.m. on March 17, Yu jumped from the fourth floor of her dormitory building in despair. After 12 days in a coma, she awoke to find that her body had become halfparalysed. She is now confined to a bed or a wheelchair.

\section{Rebuilding life}

'There's no choosing your birth, but here, you will reach your destiny. Here you need only dream, and you will soar!' reads a Foxconn recruitment slogan. The world's largest industrial company turned out to be the antithesis of Yu's dream workplace. In October 2010, eight months after her hopitalisation, under mounting public pressure Foxconn finally disbursed a one-off 'humanitarian payment' of 180,000 yuan $(\mathrm{US} \$ 27,000)$ to 'help the Tian family to go home'. In effect, the company stopped providing medical support and sent $\mathrm{Yu}$ and her parents back home in exchange for their silence about management's negligence. In the words of Yu's father, 'It was as if they were buying and selling a thing. There was no compassion, no fairness'.

However, Yu has not lost her will to 'stand up'. On returning to her birth village on November 30, 2010, she wrote to the University Research Group (my translation):

For various reasons, I had a tragedy that caused my family great suffering. During my recovery in Shenzhen, many kind-hearted university students and teachers and uncles and aunts offered encouragement and concern for my situation, and great consolation to my injured spirit. It enabled me to see life's hope and promise.

A supportive local teacher drove her from her home to a hospital in Wuhan, the provincial city of Hubei, where the treatment for her paralysis eventually enabled her to brush her teeth, wash and dress herself without too much difficulty (Ai, 2011). A combination of further treatment and personal determination has enabled her to sit up by herself and gain limited movement in her right foot.

Over three years, $\mathrm{Yu}$ has received acupuncture and massage therapy at a local hospital. At the same time, she started weaving cotton slippers to earn a little income to help pay her rehabilitation fees. Chinese netizens spread word about the colourful handwoven slippers and 'the reborn phoenix Tian Yu' (Shenzhen Daily, 22 April 2011). The harsh reality, however, is that the village is more than a five-hour drive from Wuhan, severely limiting the development of a family-based arts and handicrafts enterprise. Despite this, Yu keeps her optimistic outlook. 
I can no longer be a migrant worker, nor can I do farm work. Throughout my treatment, I thought that after being discharged from the hospital, regardless of whether I could stand or not, I must have my own income and be able to take care of myself independent of my parents and friends . . I will be a useful person to society, not a useless burden on society. Thank you for your concern. I wish you successful studies and work.

Yu's desperation is emblematic of myriad labour problems at 'the electronics workshop of the world'. During Yu's intensive medical treatment in the Shenzhen hospital, the dreams of more than a dozen young Foxconn workers were similarly shattered. How did Foxconn respond to the workplace-based suicide cluster and critical media scrutiny?

\section{The company response}

In a media interview on employee suicides, Foxconn CEO Terry Gou highlighted the 'emotional problems' of Chinese workers, while also felt compelled to take corporate responsibility: 'If a worker in Taiwan commits suicide because of emotional problems, his employer won't be held responsible, but we are taken to task in China because they are living and sleeping in our dormitories (quoted in The Straits Times, 11 June 2010)'. The company moved swiftly to control the damage to its image, announcing plans to improve conditions in the wake of the suicides. It started to require all job applicants to complete a psychological test with 36 questions. It was a victim-blaming approach. Those with 'weak capability to handle personal problems' and 'fragile spirits' were the source of the past troubles.

Foxconn left intact the underlying structures of labour-management relations, the pressures of speedup and illegal levels of compulsory overtime work, and the humiliation of workers on the shop floor, all aspects of the factory regime that are central to understanding of the young workers' deep frustrations and the continuing crisis of labour.

\section{No-suicide pledge, anti-suicide nets}

In May 2010, the Foxconn human resources director attempted to make workers sign a no-suicide pledge containing a disclaimer clause:

Should any injury or death arise for which Foxconn cannot be held accountable (including suicides and self-mutilation), I hereby agree to hand over the case to the company's legal and regulatory procedures. I myself and my family members will not seek extra compensation above that required by the law so that the company's reputation would not be ruined and its operation remains stable (China Central TV, 28 May 2010).

The no-suicide 'consent letter' sought not only to limit Foxconn's liability but to ensure that the responsibility for future suicides was placed on the individual worker. After intense criticism by workers and from wider society, Foxconn subsequently dropped this administrative requirement.

In the same month that Foxconn was making these attempts to deny responsibility for the suicides at its facilities, the suicide wave reached its appalling peak, when seven young migrant workers attempted suicide, resulting in six deaths. As an emergency measure, Foxconn placed safety nets around the roofs, on both sides of corridors, and all the windows were covered with wire and locked tight. These 'remedial measures' were taken to prevent workers from leaping to their deaths. In the two major Foxconn factory complexes in Longhua and Guanlan, where more than 500,000 workers were housed in an all-encompassing, densely-populated environment (Foxconn Technology Group, 11 October 2010), and in all its manufacturing bases across China, anti-suicide nets have now been installed. A female employee aged 16, reflected, 'I feel really constrained at Foxconn since the suicides. Now everywhere there are safety nets, they've set up these nets everywhere. It gives you a really constricted feeling. I'm depressed' (Interview, 3 December 2011).

The factory dormitory system contains a massive internal migrant labour force without the support of family networks and communal life (Pun and Smith, 2007; Pun 
and Chan, 2013). What is striking is that all the 'Foxconn dormitory safety management measures' were put in place only after the negative publicity that followed the suicides. Some netizens posted pictures of giraffes in a zoo cage, a metaphor for the experience of Foxconn workers being confined in wire-covered dorm rooms and the dehumanised nature of their working lives (Financial Times, 20 January 2012).

\section{The enterprise union: in defense of workers' rights?}

To understand why no official trade union staff members visited $\mathrm{Yu}$ in hospital or offered to assist with her problems, it is necessary to analyse the nature of the ACFTU. From 2003, the new Chinese government of $\mathrm{Hu}$ Jintao and Wen Jiabao was promoting a unionisation campaign focused on private and foreign-invested firms (Liu, 2011). As of January 2012, the Chinese trade union federation had a total membership of 258 million, of whom 36 per cent (94 million) were rural migrant workers (Xinhua, 7 January 2012). The numbers surpass the International Trade Union Confederation (ITUC) global membership of 175 million workers in 156 countries and territories excluding China (ITUC, 2012). By June 2012, 82.7 per cent of non-state companies were unionised, including various types of business entities and labour contracting companies (ACFTU, 2012). This stands in sharp contrast to the United States, where in recent decades private-sector labour unions have shrunk to a small percentage of the industrial and service workforce (Chun, 2009). In spite of impressive Chinese union membership, operational and financial dependence on management severely undermines the capacity of enterprise unions to represent the workers (Traub-Merz and Ngok, 2012). The Foxconn factory union is no exception to this pattern.

'Open and direct communication between employees and managers is the most efficient means to identify and resolve work problems and build a harmonious enterprise', stated a 2008 Foxconn company report, issued shortly after the passage of China's Labour Contract Law (Foxconn Technology Group, 2009: 16; for the requirements of the new law, see Gallagher and Dong, 2011; Wang et al., 2009; Ho, 2009; Chan, 2009). Yet, little known to the public, from 1988 through 2006, Foxconn, like many other foreign-invested enterprises, evaded its basic responsibilities and failed to set up a trade union to strengthen workers' communication with management. When the Chinese governments across different levels directly intervened in the mobilisation, the Foxconn Shenzhen Longhua factory was 'unionised' only on the last day of 2006 (IHLO, 2 January 2007). Taking immediate control over the newly formed union, Foxconn CEO Terry Gou appointed his special personal assistant, Chen Peng, to become the union chairwoman (Foxconn Technology Group, 2009: 17).

Unsurprisingly therefore, the Foxconn Trade Union failed to investigate the workplace factors responsible for the high levels of worker stress and depression. Instead, Ms Chen made insensitive public comments that 'suicide is foolish, irresponsible and meaningless and should be avoided' (quoted in China Daily, 19 August 2010). The union at Foxconn looks like, and acts like, a company union. It has failed to protect workers' health, basic rights and dignity. Thus, in one of the world's largest 'unionised' companies-over 90 per cent of the 1.4 million employees had registered as members of the union (Foxconn Technology Group, 7 June 2012), workers-like the more than 260 million rural migrant workers toiling in large and small workplaces throughout China (Xinhua, 22 February 2013)—have no trustworthy workplace-based communication channels through which to raise their voices, protect their rights or engage in collective bargaining.

\section{The government response}

Amid growing international concern over the suicides, Chinese government at all levels eventually communicated their concerns. On May 26, 2010, after the '12th jump', a Shenzhen municipal government spokesperson announced that the government would improve 'labourers' living conditions and enterprise management', and, soon 
after another attempted suicide on May 27, Guangdong provincial communist party secretary Wang Yang stated that 'the Party, government organizations and Foxconn must work together and take effective measures to prevent similar tragedies from happening again' (quoted in Beijing Review, 12 June 2010). However, the specifics of the joint measures were never disclosed.

At central government, Premier Wen Jiabao urged officials and employers to treat rural migrant workers as 'our workers, our children' (Xinhua, 15 June 2010). Yet, rather than researching and overcoming the root causes of suicides, local-level Chinese officials moved to ban 'negative' reporting about Foxconn:

May 28, 2010: About the Foxconn incident, on the Internet, other than Xinhua's domestic general draft, there should be no other reporting ... All related content before the 12th jump should be locked up ... All websites must complete the clean-up task tonight. Do not have any dead corners (China Digital Times, 30 May 2010).

May 29, 2010: For the front pages of news websites and news center pages, blogs, micro-blogs, there should be no news related to 'Foxconn' except from official sources (China Digital Times, 30 May 2010).

Beginning on May 30, 2010, the University Research Group's student blog dedicated to the Foxconn worker victims and their families, with the theme song 'Grief' was blocked. State concern about worker well-being would again be sacrificed on the altar of expediency, and the priorities were revealed to be controlling workers and the media in order to protect Foxconn.

Local states, with the trade unions as an integral part, are facilitating business activities in ways that intensify labour grievances (Friedman and Lee, 2010). An institutional conflict between legal legitimacy and local accumulation continues under China's fiscal and administrative decentralisation policies, as provincial and lower-level governments compete to woo corporate employers to invest in their territories so as to boost economic growth (Lee, 2007: 16-21). Despite legal reforms, state laws and regulations designed to protect workers are often weakly implemented or flexibly bent to company interests.

\section{Foxconn's new wage policies, work intensity and pressure}

Until the wave of worker suicides, Foxconn had never raised basic wages above the local statutory minimum levels for entry-level workers. The giant electronics company, not unlike many other private employers, has turned most of their profits into enterprise savings, dividends and reinvestment, rather than sharing with general workers. Foxconn was eventually forced to offer workers a higher wage to remain competitive in the labour market. The newly hired rural migrant workers were still between 16 and 25 years of age, come from the 'five lakes and four seas', of far-flung Chinese villages and towns. 'Pool the whole country's talent, paint splendid prospects' reads a Foxconn recruitment poster.

However, after the basic wage increase to 1,200 yuan/month (US\$192), or 9 per cent above the local minimum wage in Shenzhen city (Shenzhen Daily, 10 June 2010), Foxconn also hiked production quotas, demanding both greater labour intensity and in some cases longer hours. A worker responsible for processing cell phone casings reported: 'The production output was previously set at 5,120 pieces per day. In July 2010 , it was raised by 25 per cent to 6,400 pieces per day. I'm completely exhausted' (Interview, 30 March 2011).

During busy seasons, a working day now lasted 12 hours, which includes four hours of illegally imposed overtime. A 17-year-old working girl said, 'Every day I'm hurried along faster and faster, rushing towards each and every rising quota. There's nowhere for my mind to rest'. The effects on employee health have worsened: 'Every month we've to shift our work from day to night, and vice versa. This is a tough working life. When my body just gets used to day hours, I have to change to night hours. I really feel bad when I have my period of menstruation' (Interview, 11 November 2011). 
At the peak of the suicides, Foxconn set up a 'care hotline', first at the Shenzhen plants and then at all company factories across China. During the pilot phase in May 2010, the company reported handling 710 calls, 'including 16 who claimed they planned to commit suicide' (Xinhua, 25 May 2010). Workers can call 78585-the hotline's phonetic equivalent in Mandarin is 'please help me, help me'. However, it is highly questionable whether workers, under duress, can report confidentially without reservation through a company-run hotline and counselling service at the Employee Care Center. When some workers complained about excessive overtime, their caller identities were reported directly to management. Once aware of this breach of confidence, workers have hesitated to seek help. In another case, a worker who reported conflicts with his line leaders was advised to resign, rather than receiving supportive advice. Most worker interviewees mock the company 'care centre', dubbing it the 'supervision centre'. They have no trust in the internal 'management hotline'.

\section{Life and labour of a new generation}

From 2008 to 2012, China's minimum wage levels have registered an average 12.6 per cent annual growth rate (China Briefing, 4 January 2013), in part a response to rising worker protests, and in part an attempt to stimulate domestic consumption. The current young cohort of Chinese workers, compared with the older generation of working migrants, has greater access to news and information through mobile technologies, and has a greater expectation that their rights and interests will be protected. They demand decent working conditions and share high aspirations of living the Chinese dream' in the city. Viewed from the village, the city is where everything appears to be happening (Chan, 2013). It is against these high hopes of the second generation of rural migrant workers, whose education levels are higher than those of their predecessors, that the reality of work on the mass assembly-line at Foxconn and other factories comes as such a shock.

Not only do these young labourers, many with technical education and basic vocational skills, find themselves in low wage jobs, they also quickly discover that there is no promising route to advancement via higher education within the company. Inside Foxconn city, young workers feel deep anxiety about their future. Conscious of high burnout rates, some attempt to save enough from their meagre salaries to start small businesses in the city or elsewhere. Most quickly fail. Unfulfilled expectations of gaining skills and rising through the factory system, coupled with the inability to start small businesses, the absence of fundamental labour and citizenship rights in the city, and the frustrations of moving back and forth between city and countryside, have fuelled anger and in some a sense of helplessness (Pun and Lu, 2010; Wu, 2010; Selden and $\mathrm{Wu}, 2011)$.

Meanwhile, the position of Chinese labour is in flux as a result of demographic shifts. Under the national one child policy implemented since the late 1970s, coupled with the hypermobility of workers, Foxconn and other enterprises are experiencing incipient signs of labour shortage in coastal and inland cities (Gu and Cai, 2011; Knight et al., 2011). In the face of growing pressure on wages, Foxconn is subject to relentless demands from Apple and other electronic giants for just-in-time production, and to competition from other manufacturers bidding for contracts. The critical question is the extent and development of labour's power under Chinese and global conditions.

\section{Conclusion: moment of change?}

Foxconn's rise to become the leading global electronics manufacturer has been hailed as a success of China's export-oriented industry. However, Yu's lived experience illustrates how the company's obsession with production goals, business growth and profits frequently results in the sacrifice of the basic human needs of its workers.

Chinese sociologists have warned that the Foxconn tragedies should be seen as 'loud cries for help from the new generation of migrant workers' (Chinese Sociologists, 18 May 2010), while Taiwanese scholars have called for an end to 'military discipline' in 
the factory and the dormitory (Taiwanese Scholars, 13 June 2010). At the international level, concerned academics called on the Chinese government and industry leaders to 'establish labour standards, occupational and environmental health, and workers' dignity' in supplier factories (Concerned International Scholars, 8 June 2010).

Foxconn's management and trade union have responded by a commitment to increase productivity (by installing robotic arms in some assembly lines) and to tighten labour control. Workers nevertheless are increasingly emboldened to take actions to fight back, despite the risks of dismissal. In response, the state has frequently permitted small-scale protests and strikes ${ }^{3}$ even as it has moved vigorously to prevent organised worker actions from broadening to industry-wide or citywide scope, or the formation of independent unions (Perry, 2002; Lee, 2010; Selden and Perry, 2010).

A momentum of change is emerging as Chinese workers, concerned students and scholars, and transnational labour movement activists are joining hands to strengthen workers' power. To achieve lasting changes, it can never be sufficient to limit the discourse to corporate employers and the Chinese state. Ultimately, it is essential that workers find their voices and participate directly in monitoring and negotiating their working and living conditions. With new factory operations in booming inland cities, a substantial proportion of rural workers are being recruited from within their home province and even their home town or prefecture. The form of labour resistance for rural migrants will change as they work closer to their native place and can draw on local social networks. With a greater sense of entitlement associated with belonging to a place, and perhaps more social resources to bring to the fight for their interests, new forms of working-class power could emerge in global factories and in worker communities.

\section{Acknowledgements}

My gratitude to Debra Howcroft and Phil Taylor for their encouragement and insightful comments. I thank every Foxconn research team member and SACOM (Students and Scholars Against Corporate Misbehavior) organiser, especially Pun Ngai, Mark Selden, Debby Chan, Yiyi Cheng and Jack Qiu. I am most grateful to Jeffery Hermanson, Gregory Fay, Ralf Ruckus, Pauline Overeem, Ralph Litzinger, Michael Burawoy, Peter Evans, Amanda Bell, Dimitri Kessler, Ellen David Friedman, Paul Garver, Ian Cook, Chris Smith, Jos Gamble and Sukhdev Johal for their support. An earlier version of this paper was presented at the CRESC (Centre for Research on Socio-Cultural Change) Workshop in Senate House, the University of London on 25 April 2012, and Jenny Chan had in-depth discussions with the workshop's participants.

\section{Notes}

1. SACOM (http:/ /www.sacom.hk) was founded in 2005 to bring concerned students, scholars, labour activists and consumers together to monitor corporate behaviour and advocate workers' rights. Since 2006, SACOM has become a core member of GoodElectronics, a global network on human rights and sustainable production in the electronics industry.

2. $Q Q$ is a popular free instant messaging program operated by Tencent Holdings. The Internet domain QQ.com hosts an online community of hundreds of millions of users.

3. The right to strike was guaranteed by the Chinese Constitution of 1978, only to be removed from the Constitution of 1982. Worker strikes remain in a grey zone, neither permitted nor barred in China.

\section{References}

ACFTU (All-China Federation of Trade Unions) (2012), 'Completion of 2012 Targets on Union Construction in the Non-State Enterprises.' 19 July. Printed Version. (in Chinese).

Ai, X. (2011), 'The Citizen Camera.' Interview by Tieh-Chih Chang and Ying Qian, New Left Review 72, Nov/Dec, 63-79.

Andors, P. (1988), 'Women and Work in Shenzhen', Bulletin of Concerned Asian Scholars 20, 3, 22-41.

BBC (20 March 2012), 'Which is the World's Biggest Employer?' http:/ /www.bbc.co.uk/news/ magazine-17429786 (accessed 21 March 2012). 
Beijing Review (12 June 2010), 'Alleviating Workplace Stress.' http://www.bjreview.com.cn/ print/txt/2010-06/12/content_279444.htm (accessed 20 June 2010).

Bonacich, E. and G.G. Hamilton (2011), 'Global Logistics, Global Labor', in G.G. Hamilton, M. Petrovic and B. Senauer (eds), The Market Makers: How Retailers Are Reshaping the Global Economy (Oxford: Oxford University Press), pp. 211-230.

Chan, A. (2001), China's Workers under Assault: The Exploitation of Labor in A Globalizing Economy (Armonk, NY: M. E. Sharpe).

Chan, A. (ed.) (2011a), Walmart in China (Ithaca, NY: Cornell University Press).

Chan, A. and H. Wang (2004), 'The Impact of the State on Workers' Conditions: Comparing Taiwanese Factories in China and Vietnam', Pacific Affairs 77, 4, 629-646.

Chan, J. (2009), 'Meaningful Progress or Illusory Reform? Analyzing China's Labor Contract Law', New Labor Forum 18, 2, 43-51.

Chan, J. (2010), 'Foxconn: The Global Predator', Global Dialogue (International Sociological Association), 1, 2, 1-3. http://www.isa-sociology.org/global-dialogue/2010/11/foxconn-theglobal-predator/ (accessed 1 December 2010).

Chan, J. (2011b), 'iSlave', New Internationalist 441, 1-3. http:/ / newint.org/features/2011/04/01/ islave-foxconn-suicides-workers/ (accessed 1 April 2011).

Chan, J. (2012), 'Biting the Rotten Apple: Taking on Foxconn', Red Pepper. August. http:// www.redpepper.org.uk/biting-the-rotten-apple/ (accessed 31 August 2012).

Chan, J. (2013) 'Who Speaks for China's Workers?' 29 May. http:/ / www.labornotes.org/blogs/ 2013/05/who-speaks-china\%E2\%80\%99s-workers (accessed 30 May 2013).

Chan, J. and N. Pun (2010), 'Suicide As Protest for the New Generation of Chinese Migrant Workers: Foxconn, Global Capital, and the State', The Asia-Pacific Journal 18, 37, 1-50. http:// japanfocus.org/-Jenny-Chan/3408 (accessed 13 September 2010).

Chan, J., N. Pun and M. Selden (2013), 'The Politics of Global Production: Apple, Foxconn and China's New Working Class', New Technology, Work and Employment 28, 2, 100-115.

China Briefing (4 January 2013), 'China Initiates New Round of Minimum Wage Increases.' http://www.china-briefing.com/news/2013/01/04/china-initiates-new-round-of-minimumwage-increases.html (accessed 5 January 2013).

China Central TV (28 May 2010), 'Letter of Consent Exposed at Foxconn.' http:/ /english.cntv.cn/ program/china24/20100528/100754.shtml (accessed 29 May 2010).

China Daily (19 August 2010), 'Foxconn Rallies to End Suicides by Workers.' http:// www.chinadaily.com.cn/china/2010-08/19/content_11175517.htm (accessed 20 August 2010).

China Digital Times (30 May 2010), 'Censors and Netizens Respond to Foxconn Suicides.' http:/ / chinadigitaltimes.net/2010/05/netizens-and-censors-respond-to-foxconn-suicides/ (accessed 30 May 2010).

China Economic Review (28 May 2010), 'Crunching the Suicide Statistics at Foxconn.' http:// www.chinaeconomicreview.com/node/26618 (accessed 29 May 2010).

Chinese Sociologists (18 May 2010), 'Address to the Problems of New Generations of Chinese Migrant Workers, End to Foxconn Tragedy Now.' http://sacom.hk/archives/644 (accessed 18 May 2010).

Chun, J.J. (2009), Organizing at the Margins: The Symbolic Politics of Labor in South Korea and the United States (Ithaca, NY: Cornell University Press).

Concerned International Scholars (8 June 2010), 'Create Humane Labor Standards at Foxconn and End "Stealth Manufacturing" in Information Technology!' http://sacom.hk/archives/649 (accessed 8 June 2010).

Daily Mail (29 May 2010), 'Something Rotten at Apple's Core? Shocking Toll of Suicides at iPad Factory in China Revealed.' http:/ / www.dailymail.co.uk/news/article-1282481/iPad-factorysuicides-China.html (accessed 30 May 2010).

Day, A. and M.A. Hale (2007), 'Guest Editors' Introduction', Chinese Sociology and Anthropology 39, 4, 3-9.

Financial Times (20 January 2012), 'Terry Gou: Managing "1 Million Animals." ' http://blogs .ft.com/beyond-brics/2012/01/20/terry-gou-managing-1-million-animals/\#axzz24Gpqlfho (accessed 21 January 2012).

Foxconn Technology Group (2009), '2008 Corporate Social and Environmental Responsibility Annual Report.' http:/ / ser.foxconn.com/ViewAnuReport.do?action=showAnnual (accessed 1 February 2013).

Foxconn Technology Group (11 October 2010), 'Foxconn is Committed to a Safe and Positive Working Environment.' http://sacom.hk/wp-content/uploads/2010/10/foxconn_media statement_oct_11.pdf (accessed 11 October 2010).

Foxconn Technology Group (7 June 2012), 'Foxconn Response to SACOM Report "Sweatshops are Good for Apple and Foxconn, But Not for Workers."' http:/ / www.business-humanrights.org/ 
Search/SearchResults?SearchableText=Sweatshops+are+good+for+Apple+and+Foxconn

$\% 2 \mathrm{C}+$ but+not+for+workers\& $\mathrm{x}=12 \& \mathrm{y}=5$ (accessed 7 June 2012).

Friedman, E. and C.K. Lee (2010), 'Remaking the World of Chinese Labour: A 30-Year Retrospective', British Journal of Industrial Relations 48, 3, 507-533.

Gallagher, M.E. and B. Dong (2011), 'Legislating Harmony: Labor Law Reform in Contemporary China', in S. Kuruvilla, C.K. Lee and M.E. Gallagher (eds), From Iron Rice Bowl to Informalization: Markets, Workers, and the State in A Changing China (Ithaca, NY: Cornell University Press), pp. 36-60.

Gu, B. and Y. Cai (2011), 'Fertility Prospects in China.' United Nations Population Division, Expert Paper No. 2011/14. http:/ / www.un.org/esa/population/publications/expertpapers/ 2011-14_Gu\&Cai_Expert-paper.pdf (accessed 20 April 2012).

Harney, A. (2008), The China Price: The True Cost of Chinese Competitive Advantage (New York: The Penguin Press).

Ho, V.E.H. (2009), 'From Contracts to Compliance? An Early Look at Implementation under China's New Labor Legislation', Columbia Journal of Asian Law 23, 1, 33-107. http:// papers.ssrn.com/sol3/papers.cfm?abstract_id=1432708 (accessed 30 December 2010).

Hsing, Y. (1998), Making Capitalism in China: The Taiwan Connection (New York: Oxford University Press).

Hung, H. (2013), 'Labor Politics under Three Stages of Chinese Capitalism', The South Atlantic Quarterly 112, 1, 203-212.

IHLO (International Trade Union Confederation/Global Union Federation Hong Kong Liaison Office) (2007), 'ACFTU (All-China Federation of Trade Unions) Established a Union at Foxconn on the Very Last Day of 2006.' http://www.ihlo.org/LRC/ACFTU/030107.html (accessed 10 January 2007).

iSuppli (30 May 2006), 'Foxconn Takes Number One Rank in EMS [Electronics Manufacturing Services]. http://www.emsnow.com/npps/story.cfm?ID=19523 (accessed 31 May 2006).

iSuppli (27 July 2010), 'Foxconn Rides Partnership with Apple to Take 50 Per cent of EMS [Electronic Manufacturing Services] Market in 2011.' http://www.isuppli.com/ Manufacturing-and-Pricing/News/Pages/Foxconn-Rides-Partnership-with-Apple-to-Take50-Percent-of-EMS-Market-in-2011.aspx (accessed 28 July 2010).

ITUC (International Trade Union Confederation) (2012), 'List of Affiliated Organizations.' http:/ / www.ituc-csi.org/IMG/pdf/no_03_-_list_affiliates___010213.pdf (accessed 5 January 2013).

Jacka, T. (2006), Rural Women in Urban China: Gender, Migration and Social Change (Armonk, NY: M. E. Sharpe).

Ji, J., A. Kleinman and A.E. Becker (2001), 'Suicide in Contemporary China: A Review of China's Distinctive Suicide Demographics in Their Sociocultural Context', Harvard Review of Psychiatry 9, 1, 1-12.

Knight, J., Q. Deng and S. Li (2011), 'The Puzzle of Migrant Labour Shortage and Rural Labour Surplus in China', China Economic Review 22, 585-600.

Lee, C.K. (1998), Gender and the South China Miracle: Two Worlds of Factory Women (Berkeley, CA: University of California Press).

Lee, C.K. (2007), Against the Law: Labor Protests in China's Rustbelt and Sunbelt (Berkeley, CA: University of California Press).

Lee, C.K. (2010), 'Pathways of Labor Activism', in E.J. Perry and M. Selden (eds), Chinese Society: Change, Conflict and Resistance, 3rd edn (London: Routledge), pp. 57-79.

Lee, S. and A. Kleinman (2003), 'Suicide As Resistance in Chinese Society', in E.J. Perry and M. Selden (eds), Chinese Society: Change, Conflict and Resistance, 2nd edn (London: RoutledgeCurzon), pp. 294-317.

Lichtenstein, N. (2009), The Retail Revolution: How Wal-Mart Created A Brave New World of Business (New York: Metropolitan Books).

Litzinger, R.A. (2013), 'The Labor Question in China: Apple and Beyond', The South Atlantic Quarterly 112, 1, 172-178.

Liu, M. (2011), " Where There Are Workers, There Should Be Trade Unions": Union Organizing in the Era of Growing Informal Employment', in S. Kuruvilla, C.K. Lee and M.E. Gallagher (eds), From Iron Rice Bowl to Informalization: Markets, Workers, and the State in A Changing China (Ithaca, NY: Cornell University Press), pp. 157-172.

Lucas, K., D. Kang and Z. Li (2013), 'Workplace Dignity in A Total Institution: Examining the Experiences of Foxconn's Migrant Workforce', Journal of Business Ethics 114, 1, 91-106.

Mills, C.W. ([1959] 2000), The Sociological Imagination (Oxford: Oxford University Press).

Perry, E.J. (2002), Challenging the Mandate of Heaven: Social Protest and State Power in China (Armonk, NY: M.E. Sharpe). 
Phillips, M.R., X. Li and Y. Zhang (2002), 'Suicide Rates in China, 1995-99', The Lancet 359, 835-840.

Pringle, T. (2013), 'Reflections on Labor in China: From A Moment to A Movement', The South Atlantic Quarterly 112, 1, 191-202.

Pun, N. (2005), Made in China: Women Factory Workers in A Global Workplace (Durham: Duke University Press).

Pun, N. and J. Chan (2012), 'Global Capital, the State, and Chinese Workers: The Foxconn Experience', Modern China 38, 4, 383-410.

Pun, N. and J. Chan (2013), 'The Spatial Politics of Labor in China: Life, Labor, and A New Generation of Migrant Workers', The South Atlantic Quarterly 112, 1, 179-190.

Pun, N. and H. Lu (2010), 'Unfinished Proletarianization: Self, Anger, and Class Action among the Second Generation of Peasant-Workers in Present-Day China', Modern China 36, 5, 493519.

Pun, N. and C. Smith (2007), 'Putting Transnational Labour Process in Its Place: The Dormitory Labour Regime in Post-Socialist China', Work, Employment \& Society 21, 1, 27-45.

Selden, M. (1993), The Political Economy of Chinese Development (Armonk, NY: M. E. Sharpe).

Selden, M. and E.J. Perry (2010), 'Introduction: Reform, Conflict and Resistance in Contemporary China', in E.J. Perry and M. Selden (eds), Chinese Society: Change, Conflict and Resistance, 3rd edn (London: Routledge), pp. 1-30.

Selden, M. and J. Wu (2011), 'The Chinese State, Incomplete Proletarianization and Structures of Inequality in Two Epochs', The Asia-Pacific Journal 9, 5, 1-35. http://japanfocus.org/-MarkSelden/3480 (accessed 31 January 2011).

Shenzhen Daily (10 June 2010), 'Minimum Wage to Rise to RMB1,100.' http:/ /english.sz.gov.cn/ $\ln / 201006 /$ t20100610_1546188.htm (accessed 11 June 2010).

Shenzhen Daily (22 April 2011). “"Suicide Girl” Regains Optimism.' http://www.szdaily.com/ content/2011-04/22/content_5559657.htm (accessed 23 April 2011).

South China Morning Post (19 July 2012), 'Struggle for Foxconn Girl who Wanted to Die.' http:/ / www.scmp.com/article/733389/struggle-foxconn-girl-who-wanted-die (accessed 20 July 2012).

South China Morning Post $(25$ April 2013), 'Foxconn Suicide Survivor Says No Job is Worth Ending Your Life Over.' http://www.scmp.com/news/china/article/1222225/foxconnsuicide-survivor-says-no-job-worth-ending-your-life-over (accessed 26 April 2013).

Taiwanese Scholars (13 June 2010), 'The Foxconn Employees and to Call to the Attention.' https: / sites.google.com/site/laborgogo2010eng/ (accessed 13 June 2010).

The Guardian (28 May 2010), 'Foxconn Offers Pay Rises and Suicide Nets as Fears Grow Over Wave of Deaths.' http://www.guardian.co.uk/world/2010/may/28/foxconn-plant-china-deathssuicides (accessed 30 May 2010).

The Straits Times (11 June 2010), 'It's Time to Dismantle Factory Towns.' http:/ /www.chinapost. com.tw/commentary/the-china-post/special-to-the-china-post/2010/06/11/260248/p1/ It\%27s-time.htm (accessed 20 June 2010).

Traub-Merz, R. and K. Ngok (eds) (2012), Industrial Democracy in China: With Additional Studies on Germany, South-Korea and Vietnam (Beijing: China Social Sciences Press), http:// chinastudygroup.net/wp-content/uploads/2012/07/Industrial-Democracy-2012.pdf (accessed 2 January 2013).

Wang, H., R.P. Appelbaum, F. Degiuli and N. Lichtenstein (2009), 'China's New Labor Contract Law: Is China Moving Towards Increased Power for Workers?', Third World Quarterly 30, 3, 485-501.

Webster, E., R. Lambert and A. Bezuidenhout (2008), Grounding Globalization: Labour in the Age of Insecurity (Malden, MA: Blackwell Publishing).

Wu, J. (2010), ‘Rural Migrant Workers and China's Differential Citizenship: A Comparative Institutional Analysis', in M.K. Whyte (ed.), One Country, Two Societies: Rural-Urban Inequality in Contemporary China (Cambridge: Harvard University Press), pp. 55-81.

Xinhua (25 May 2010), 'Another Foxconn Employee Falls to Death at Shenzhen Factory.' http:/ / news.xinhuanet.com/english2010/china/2010-05/25/c_13313857.htm (accessed 26 May 2010).

Xinhua (15 June 2010), 'Wen Calls for Improving Migrant Workers' Living Conditions.' http:/ / www.chinadaily.com.cn/china/2010-06/15/content_9978294.htm (accessed 20 June 2010).

Xinhua (7 January 2012), '20\% of Chinese Join Trade Unions.' http:/ / www.chinadaily.com.cn/ china/2012-01/07/content_14400312.htm (accessed 10 January 2012).

Xinhua (22 February 2013), 'Rural Migrant Workers Top 262 Million.' http://www.chinadaily. com.cn/china/2013-02/22/content_16249365.htm (accessed 25 February 2013).

Yan, H. (2008), New Masters, New Servants: Migration, Development, and Women Workers in China (Durham: Duke University Press). 